\title{
Organocatalytic Asymmetric Synthesis of Functionalized 3,4-Dihydropyran Derivatives
}

\author{
Patrick T. Franke, Bo Richter, and Karl Anker Jørgensen*[a]
}

In the last few years, the field of organocatalysis has attracted much attention in the chemical community. ${ }^{[1]}$ It has been proven to be a useful tool in the development of new methodologies in order to obtain easy stereoselective access to optically active molecules of, for example, biological importance. Chiral secondary amines are very powerful organocatalysts giving rise to highly stereoselective transformations of carbonyl compounds, such as the enantioselective $\alpha^{[2]}-, \beta^{[3]}$, and $\gamma^{[4]}$-functionalization of aldehydes. Furthermore, a new concept dealing with singly occupied molecular orbital (SOMO) organocatalysis ${ }^{[5]}$ has emerged recently. In these reactions the chiral secondary amines catalyze the formation of a single bond and stereocenter; however, a further advantage of these compounds in organocatalysis is the possibility to obtain multiple bonds and new stereocenters in terms of diastereo- and enantioselective domino, one-pot, and multicomponent reactions. ${ }^{[6]}$

A large group of important natural products, such as carbohydrates, alkaloids, polyether antibiotics, pheromones and iridoids, contain polyfunctionalized pyran derivatives as subunits. ${ }^{[7]}$ The common way to access 3,4 -dihydropyrans is, for example, by an inverse-electron-demanding hetero-DielsAlder reaction between $\alpha, \beta$-unsaturated carbonyl compounds with electron-rich alkenes. ${ }^{[8]}$ We envisioned that it might be possible to develop an organocatalytic reaction for the formation of enantiomerically enriched 3,4-dihydropyrans as outlined in Scheme 1. This strategy is based on the initial Michael addition of a 1,3-cycloalkanedione to an $\alpha, \beta$ unsaturated aldehyde in the presence of an organocatalyst followed by a subsequent cyclization reaction.

Initial studies showed that the addition of 1,3-cyclopentadione to $\alpha, \beta$-unsaturated aldehydes, which after cyclization

[a] P. T. Franke, B. Richter, Prof. Dr. K. A. Jørgensen

Danish National Research Foundation:

Center for Catalysis Department of Chemistry

Aarhus University, 8000 Aarhus C (Denmark)

Fax: (+45) 8919-6199

E-mail:kaj@chem.au.dk

Supporting information for this article is available on the WWW under http://dx.doi.org/10.1002/chem.200800850.

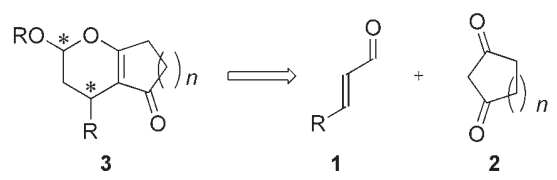

Scheme 1. Retrosynthetic analysis.

results in the formation of 3,4-dihydropyrans, proceeds in toluene under slightly acidic conditions in the presence of a secondary amine as the catalyst. With these promising findings in hand, we performed a screening in order to optimize the conditions in the reaction of cinnamaldehyde $\mathbf{1 a}$ with 1,3-cyclopentadione $\mathbf{2}$ a.

Various organocatalysts $4 \mathbf{a}-\mathbf{e}$, solvents and reaction temperatures were tested and a selection of results is presented in Table 1 . The screening of different secondary amines as catalysts in toluene revealed that $(S)$-2-[bis(3,5-bistrifluoromethylphenyl)trimethyl-silanyloxymethyl]pyrrolidine $(\mathbf{4 a})^{[9]}$ gave full conversion affording the 3,4-dihydropyran 3a with $72 \%$ ee (Table 1, entry 1). Surprisingly, when $(S)$-2-(diphenyl(trimethylsilyloxy)methyl)pyrrolidine (4b) was used as the catalyst, no formation of $\mathbf{3 a}$ was detected (Table 1, entry 2). Proline 4d, as well as proline amide $\mathbf{4 e}$, were unable to catalyze the reaction (Table 1 , entries 4,5 ). The use of $(S)$-diphenyl(pyrrolidin-2-yl)methanol (4c) resulted in $38 \%$ yield and $-40 \%$ ee (Table 1 , entry 4 ). To our surprise, even though both catalyst $\mathbf{4 a}$ and $\mathbf{4 c}$ are derived from the $(S)$-conformation, the opposite enantiomers of $\mathbf{3 a}$ are formed in these reactions. ${ }^{[10]}$

After finding the appropriate catalyst for the reaction, different solvents and temperatures were screened. Choosing $\mathrm{CH}_{2} \mathrm{Cl}_{2}$ at ambient temperature as the solvent increased the yield of $\mathbf{3 a}$ to $59 \%$ and the enantioselectivity to $75 \%$ ee (Table 1, entry 6). Less promising results were obtained in EtOH and $\mathrm{Et}_{2} \mathrm{O}$, compared with toluene (Table 1, entries 7, 8). Using $\mathrm{CH}_{2} \mathrm{Cl}_{2}$ and lowering the temperature to $4{ }^{\circ} \mathrm{C}$ allowed $65 \%$ of the product to be isolated with an enantioselectivity of $84 \%$ ee (Table 1, entry 9). Further improvement was obtained by performing the reaction at $-35^{\circ} \mathrm{C}$ which afforded the final key parameters: temperature at $-35^{\circ} \mathrm{C}$, 
Table 1. Screening of reaction conditions for the addition of $\mathbf{2 a}$ to $\alpha, \beta$ unsaturated aldehyde $\mathbf{1} \mathbf{a}$ with subsequent cyclization in the presence of secondary amines $\mathbf{4}$ as catalyst. ${ }^{[a]}$

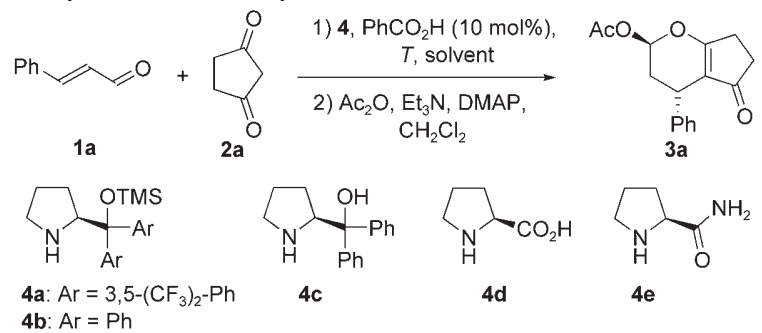

\begin{tabular}{llcllll}
\hline Entry & Solvent & Catalyst & $T$ & ${\text { Yield }[\%]^{[\mathrm{b}]}}$ & d.r. $^{[\mathrm{c}]}$ & $e e[\%]^{[\mathrm{d}]}$ \\
\hline 1 & toluene & $\mathbf{4 a}$ & $\mathrm{RT}$ & 42 & $4: 1$ & 72 \\
2 & toluene & $\mathbf{4 b}$ & $\mathrm{RT}$ & n.r. & n.r. & n.r. \\
3 & toluene & $\mathbf{4 c}$ & $\mathrm{RT}$ & 38 & $4: 1$ & $-40^{[\mathrm{e}]}$ \\
4 & toluene & $\mathbf{4 d}$ & $\mathrm{RT}$ & n.r. & n.r. & n.r. \\
5 & toluene & $\mathbf{4 e}$ & $\mathrm{RT}$ & n.r. & n.r. & n.r. \\
6 & $\mathrm{CH}_{2} \mathrm{Cl}{ }_{2}$ & $\mathbf{4 a}$ & $\mathrm{RT}$ & 59 & $3: 1$ & 75 \\
7 & $\mathrm{EtOH}$ & $\mathbf{4 a}$ & $\mathrm{RT}$ & 66 & n.d. & 67 \\
8 & $\mathrm{Et}_{2} \mathrm{O}$ & $\mathbf{4 a}$ & $\mathrm{RT}$ & 63 & $5: 1$ & 64 \\
9 & $\mathrm{CH}_{2} \mathrm{Cl}_{2}$ & $\mathbf{4 a}$ & $4^{\circ} \mathrm{C}$ & 65 & $3: 1$ & 84 \\
10 & $\mathrm{CH}_{2} \mathrm{Cl}_{2}$ & $\mathbf{4 a}$ & $-35^{\circ} \mathrm{C}$ & $85^{[\mathrm{f}]}$ & $3: 1$ & 90 \\
\hline
\end{tabular}

[a] Performed with 1a $(0.75 \mathrm{mmol}), 2$ a $(0.25 \mathrm{mmol}), 4(0.025 \mathrm{mmol})$ and $\mathrm{PhCO}_{2} \mathrm{H}(0.025 \mathrm{mmol})$ in $0.5 \mathrm{~mL}$ of solvent; after complete conversion of 2a (ca. $12 \mathrm{~h}$ ) the acetylation was performed $(2 \mathrm{~h})$. [b] Overall yield of both diastereomers after FC. [c] Diastereomeric ratio determined by 1H NMR spectroscopy of the crude mixture. [d] Determined by chiralstationary-phase HPLC (see the Supporting Information). [e] Inverted selectivity was observed. [f] Reaction time increased to $24 \mathrm{~h}$.

$\mathrm{CH}_{2} \mathrm{Cl}_{2}$ as the solvent and $(S)$-2-[bis(3,5-bistrifluoromethylphenyl)trimethyl-silanyloxymethyl]pyrrolidine (4a) as the catalyst. Under these conditions, dihydropyran 3a was formed in $85 \%$ yield and with $90 \%$ ee (Table 1, entry 10).

With the optimized reaction conditions in hand, we investigated the scope of the reaction. In Table 2 the results obtained for the reaction of aromatic and alkyl $\alpha, \beta$-unsaturated aldehydes $\mathbf{1} \mathbf{a}-\mathbf{m}$ with 1,3-cyclopentadione $\mathbf{2 a}$ and the subsequent cyclization to the dihydropyrans $\mathbf{3}$ are presented.

It appears that a broad range of different types of $\alpha, \beta$-unsaturated aldehydes are tolerated under the reaction conditions used. Among these tolerated substituents are aliphatics, esters, aromatic and heteroaromatic groups, and double bonds. Employing aromatic groups resulted in a mixture of diastereomers in the range from $2: 1$ to $5: 1$ in good yields and with enantioselectivities up to $92 \%$ ee (Table 2, entries 1, 2 and 5-7).

Performing the reaction with heteroaromatic substituents increased the diastereoselectivity providing a d.r. of up to $5: 1$ and in the case of (E)-3-(thiophen-2-yl)acrylaldehyde (1d), dihydropyran 3d could be isolated in $95 \%$ yield and with $93 \%$ ee (Table 2 , entries 3,4$)$. The use of alkyl $\alpha, \beta$-unsaturated aldehydes gave comparable diastereoselectivities in consistently good yields and with enantioselectivities in the range from $84-96 \%$ ee (Table 2, entries 8-13). The best selectivity was obtained with the $\alpha, \beta$-unsaturated aldehyde $1 \mathbf{m}$ where only one diastereomer could be detected (Table 2, entry 13). The reaction could also be scaled up to
Table 2. Scope, yield and enantioselectivity of the organocatalytic asymmetric synthesis of optically active dihydropyrans. ${ }^{[a]}$

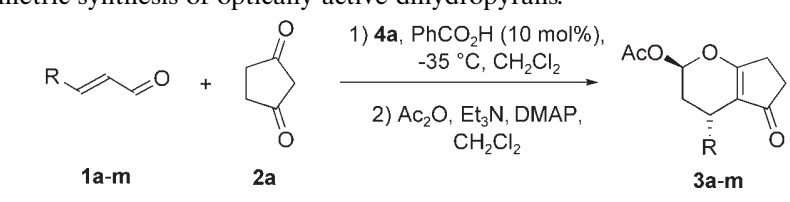

\begin{tabular}{|c|c|c|c|c|c|}
\hline Entry & $\mathrm{R}$ & d.r. ${ }^{[b]}$ & Product & Yield $[\%]^{[\mathrm{c}]}$ & $e e[\%]^{[\mathrm{d}]}$ \\
\hline 1 & $\mathrm{Ph}(\mathbf{1} \mathbf{a})$ & $3: 1$ & $3 \mathbf{a}$ & $85^{[\mathrm{e}]}$ & 90 \\
\hline 2 & $p-\mathrm{F}-\mathrm{Ph}(\mathbf{1} \mathbf{b})$ & $7: 2$ & 3b & 82 & 88 \\
\hline 3 & 2-furyl (1c) & $9: 2$ & $3 \mathbf{c}$ & $85^{[e]}$ & 82 \\
\hline 4 & 2-thiophene (1d) & $5: 1$ & 3d & 95 & 93 \\
\hline 5 & $o-\mathrm{Br}-\mathrm{Ph}(\mathbf{1 e})$ & $3: 1$ & $3 \mathbf{e}$ & 59 & 92 \\
\hline 6 & $o-\mathrm{NO}_{2}-\mathrm{Ph}(\mathbf{1} \mathbf{f})$ & $2: 1$ & $3 \mathbf{f}$ & $65^{[\mathrm{e}]}$ & 92 \\
\hline 7 & $o-\mathrm{CF}_{3}-\mathrm{Ph}(\mathbf{1 g})$ & $5: 2$ & $3 \mathbf{g}$ & 69 & 91 \\
\hline 8 & Bn (1h) & $2: 1$ & $3 \mathbf{h}$ & 85 & 95 \\
\hline 9 & $\operatorname{Me}(\mathbf{1 i})$ & $7: 2$ & $3 \mathbf{i}$ & 74 & 84 \\
\hline 10 & Et $(\mathbf{1} \mathbf{j})$ & $5: 2$ & $\mathbf{3 j}$ & 74 & 93 \\
\hline 11 & $i \operatorname{Pr}(\mathbf{1 k})$ & $5: 2$ & $3 \mathbf{k}$ & 74 & 94 \\
\hline 12 & hex-3-en-1-yl (11) & $2: 1$ & 31 & 81 & 96 \\
\hline 13 & $\mathrm{CO}_{2} \mathrm{Et}(\mathbf{1} \mathbf{m})$ & $>20: 1^{[\mathrm{f}]}$ & $3 \mathrm{~m}$ & 48 & 88 \\
\hline 14 & $\mathrm{Ph}(\mathbf{1} \mathbf{a})$ & $3: 1$ & $3 \mathbf{a}$ & $71^{[\mathrm{g}]}$ & 88 \\
\hline
\end{tabular}

[a] Performed with 1a $(0.25 \mathrm{mmol}), \mathbf{2 a}(0.30 \mathrm{mmol}), \mathbf{4}(0.025 \mathrm{mmol})$ and $\mathrm{PhCO}_{2} \mathrm{H}(0.025 \mathrm{mmol})$ in toluene $(0.5 \mathrm{~mL})$ at $-35^{\circ} \mathrm{C}$; after complete conversion of $2 \mathbf{a}$ (ca. $24 \mathrm{~h}$ ) the acetylation was performed $(2 \mathrm{~h})$ at room temperature. [b] Diastereomeric ratio determined by $1 \mathrm{H}$ NMR spectroscopy of the crude mixture. [c] Overall yield of both diastereomers after FC. [d] Determined by chiral-stationary-phase HPLC (see the Supporting Information). [e] $0.75 \mathrm{mmol}$ of the aldehyde were used. [f] Only one diastereomer detected. [g] Performed on a $10 \mathrm{mmol}$ scale using $5 \mathrm{~mol} \%$ catalyst with a reaction time of $72 \mathrm{~h}$ at $-20^{\circ} \mathrm{C}$.

$10 \mathrm{mmol}$, only with a slight decrease in yield, but maintaining the enantio- and diastereoselectivity at high levels (Table 2, entry 14).

After varying the substituents of the $\alpha, \beta$-unsaturated aldehydes we also varied the ring size of the nucleophile. For the addition of 1,3-cyclohexanedione $\mathbf{2} \mathbf{b}$ to cinnamaldehyde 1a, the product $\mathbf{3}$ n was obtained in a 4:1 mixture of diastereomers and with an excellent enantioselectivity of $97 \% e e$ (Scheme 2). Even better results with respect to diastereoselectivity and yield were achieved by using the seven-membered cyclic dione $\mathbf{2 c}$ where $77 \%$ yield, a d.r. of $>8: 1$ and $97 \%$ ee of the major diastereomer are obtained. (Scheme 2).

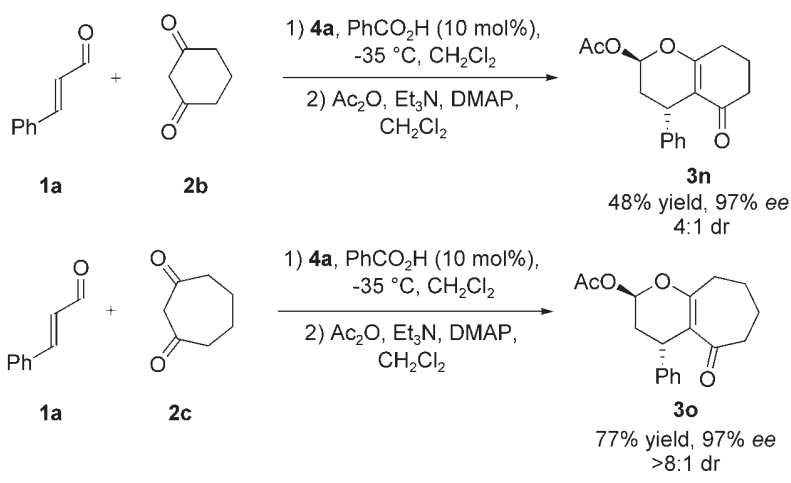

Scheme 2. Asymmetric synthesis of 3,4-dihydropyrans. 
The proposed mechanism for the reaction course is summarized in Scheme 3. The Michael addition follows the common path previously reported in the literature. ${ }^{[3 \mathrm{f}, \mathrm{p}, 6 \mathrm{p}, \mathrm{r}, \mathrm{u}]}$

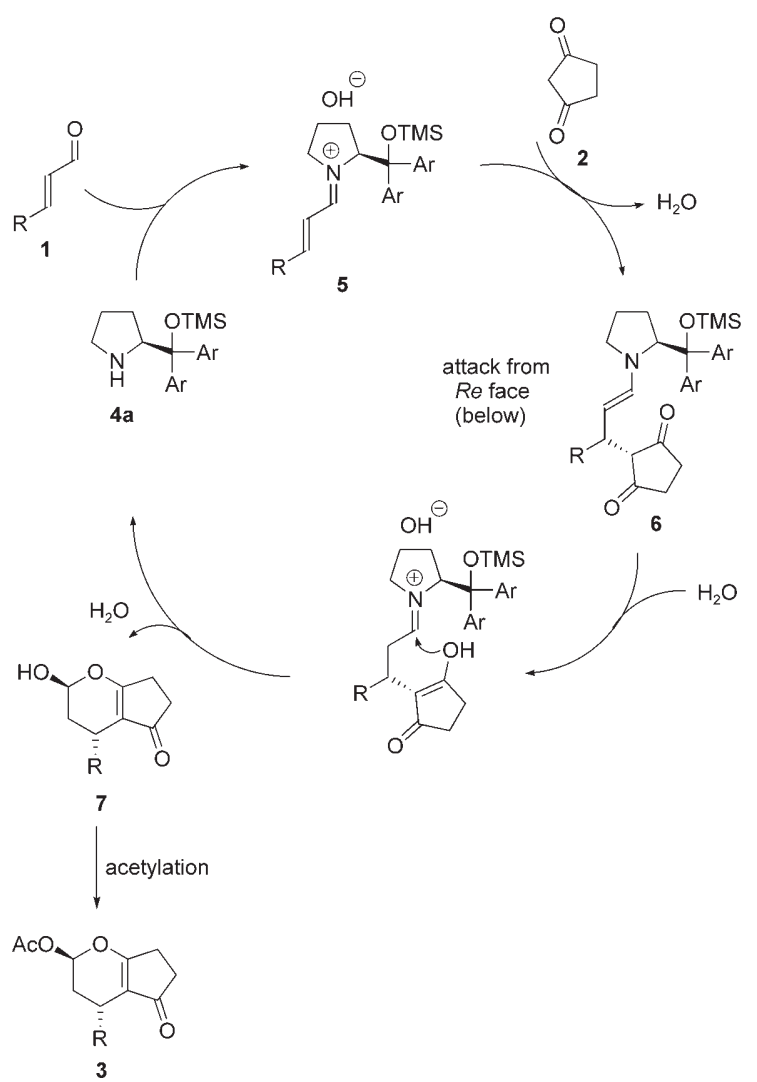

Scheme 3. Proposed mechanism for the organocatalytic one-pot Michael addition of $\alpha, \beta$-unsaturated aldehydes $\mathbf{1}$ and 1,3-cyclopentadione $\mathbf{2}$ to afford chiral dihydropyrans $\mathbf{3}$.

The $\alpha, \beta$-unsaturated aldehyde $\mathbf{1}$ is transformed by catalyst $4 \mathbf{a}$ and nucleophile $\mathbf{2}$ into the Michael adduct $\mathbf{6}$. The stereocenter formed in the catalytic cycle is controlled by a $R e$ face attack of the nucleophile on the planar iminium ion $\mathbf{5}$. The $R e$ face of the $\beta$-carbon atom in the iminium-ion intermediate is favored for approach of the nucleophile owing to the bulk of the $\mathrm{C} 2$-substituent in the pyrrolidine ring of the catalyst which shields the $S i$ face, previously reported for the use of TMS-protected prolinols as organocatalysts. ${ }^{[3 f, p, 6 p, r, u]}$ After the formation of the stereocenter, the catalyst is released by cyclization to form the hemi-acetal $\mathbf{7}$. For separation purposes $\mathbf{7}$ is easily acetylated to afford $\mathbf{3}$.

Finally, we determined the absolute configuration of the major stereoisomer by single-crystal X-ray analysis of the unprotected compound $\mathbf{8 b}$ derived from $\mathbf{3 e}$, where the chiral centers were determined as $2 S / 4 R$ (Figure 1). ${ }^{[1]}$ The absolute configuration of the initially formed stereocenter indicates that the addition of the nucleophile approaches from the $R e$ face through the control of the catalyst. The initially formed stereocenter for the minor diastereomer is the same as the major diastereomer. The configuration of the remaining compounds is assumed by analogy.

Scheme 4 outlines some transformations of the optically active dihydropyrans formed. A desymmetrization of one ketone affording aldehyde 9 was achieved when the unprotected 3,4dihydropyran 8a $(\mathrm{R}=\mathrm{H})$ was treated with methanesulfonyl chloride. Furthermore, by react-

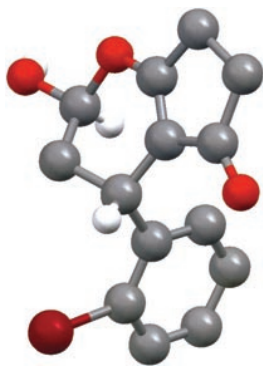

Figure 1. X-ray structure of unprotected derivative of compound 3e. $\mathrm{C}$ gray, $\mathrm{H}$ white, $\mathrm{O}$ red, $\mathrm{Br}$ brown. pound $10 \quad(\mathrm{R}=\mathrm{TBS})$ with a Grignard reagent $\alpha, \beta$-functionalized cyclopent-2-enone $\mathbf{1 1}$ could be accessed in $40 \%$ yield. The lactone $\mathbf{1 2}$ can be obtained according to the procedure developed recently by Rueping et al. ${ }^{[3 \mathrm{~s}]}$

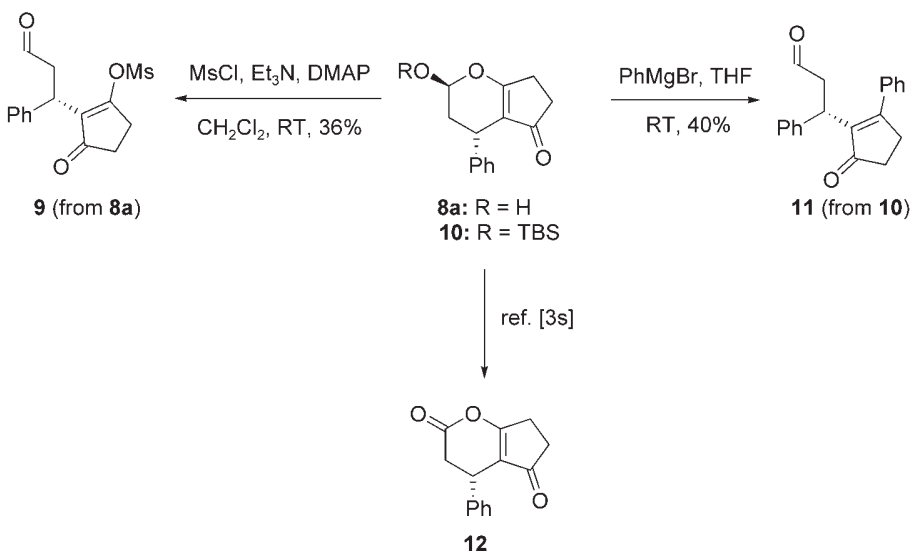

Scheme 4. Elaboration of the 3,4-dihydropyrans.

In conclusion, we have developed the organocatalytic enantioselective addition of 1,3-cycloalkanediones to $\alpha, \beta$-unsaturated aldehydes obtaining 3,4-dihydropyrans with excellent enantioselectivies and good diastereoselectivities for a broad range of aromatic and aliphatic aldehydes. These compounds could afterwards be transformed to various interesting derivatives.

\section{Experimental Section}

Synthesis of adducts 3: An ordinary vial equipped with a magnetic stirring bar was charged with catalyst 3 a $(0.025 \mathrm{mmol}, 10 \mathrm{~mol} \%), \mathrm{PhCO}_{2} \mathrm{H}$ $(0.025 \mathrm{mmol}, 10 \mathrm{~mol} \%)$ and $\mathrm{CH}_{2} \mathrm{Cl}_{2}(0.50 \mathrm{~mL})$. Then, the solution was cooled to $-35^{\circ} \mathrm{C}$ and the $\alpha, \beta$-unsaturated aldehyde $1(0.25 \mathrm{mmol})$ and the 1,3 -cyclodione $2(0.25 \mathrm{mmol})$ were added. The stirring was maintained at $-35^{\circ} \mathrm{C}$ for about $24 \mathrm{~h}$ until completion of the reaction. To the reaction mixture $\mathrm{CH}_{2} \mathrm{Cl}_{2}(1.5 \mathrm{~mL}), \mathrm{Ac}_{2} \mathrm{O}(0.75 \mathrm{mmol}), \mathrm{Et}_{3} \mathrm{~N}(0.10 \mathrm{~mL})$ and DMAP (catalytic amount) were added and stirred at ambient temperature for about $2 \mathrm{~h}$. The reaction mixture was poured into $\mathrm{H}_{2} \mathrm{O}$ $(10 \mathrm{~mL})$, extracted with EtOAc $(3 \times 10 \mathrm{~mL})$, dried over $\mathrm{MgSO}_{4}$, evaporat- 
ed and then loaded onto silica gel and the products $\mathbf{3 a}$ a-o were obtained by flash chromatography.

Representative example: $(2 R, 4 S)$-5-oxo-4-phenyl-2,3,4,5,6,7-hexahydrocyclopenta[b]pyran-2-yl acetate (3a) was isolated by FC using silica gel $(n$ hexane/AcOEt $3: 1$ ) as an oil in $85 \%$ yield as a mixture of diastereomers (3:1). Major diastereomer: ${ }^{1} \mathrm{H}$ NMR $\left(400 \mathrm{MHz}, \mathrm{CDCl}_{3}\right): \delta=7.33-7.29$ $(\mathrm{m}, 2 \mathrm{H}), 7.27-7.21(\mathrm{~m}, 1 \mathrm{H}), 7.19-7.13(\mathrm{~m}, 2 \mathrm{H}), 6.38(\mathrm{dd}, J=6.1,2.5 \mathrm{~Hz}$, $1 \mathrm{H}), 3.85(\mathrm{t}, J=6.5 \mathrm{~Hz}, 1 \mathrm{H}), 2.78-2.58(\mathrm{~m}, 2 \mathrm{H}), 2.55-2.43(\mathrm{~m}, 2 \mathrm{H}), 2.32$ $2.20(\mathrm{~m}, 1 \mathrm{H}), 2.16(\mathrm{~s}, 3 \mathrm{H}), 2.06-2.00 \mathrm{pppm}(\mathrm{m}, 1 \mathrm{H}) ;{ }^{13} \mathrm{C}$ NMR $(100 \mathrm{MHz}$, $\left.\mathrm{CDCl}_{3}\right): \delta=202.1,182.0,169.0,140.9,128.6,127.3,126.9,116.7,91.3$, 34.4, 33.4, 31.9, 26.0, 20.9 ppm; HRMS: $m / z$ : calcld for $\mathrm{C}_{16} \mathrm{H}_{16} \mathrm{O}_{4} \mathrm{Na}$ : 295.0946; found: $295.0952[M+\mathrm{H}]^{+}$. The $e e$ was determined by HPLC analysis using a Chiralpak AD column (hexane/ $i \mathrm{PrOH}$ 90:10); flow rate $1.0 \mathrm{~mL} \mathrm{~min}^{-1} ; \tau_{\text {major }}=6.5, \tau_{\text {minor }}=8.1 \min (90 \% e e) .[\alpha]_{\mathrm{D}}^{\mathrm{RT}}=+24.6(c=$ $1.0, \mathrm{CH}_{2} \mathrm{Cl}_{2}$ ).

\section{Acknowledgements}

This work was made possible by a grant from Danish National Research Foundation. Thanks are expressed to Dr. Jacob Overgaard for performing X-ray analysis.

Keywords: asymmetric synthesis - conjugate addition cyclization $\cdot$ organocatalysis $\cdot$ pyrans

[1] For recent reviews on organocatalysis see, for example: a) P. I. Dalko, L. Moisan, Angew. Chem. 2004, 116, 5248; Angew. Chem. Int. Ed. 2004, 43, 5138; b) A. Berkessel, H. Gröger, Asymmetric Organocatalysis, VCH, Weinheim (Germany), 2004; c) Acc. Chem. Res. 2004, 37, Issue 8, special issue on organocatalysis; d) J. Seayed, B. List, Org. Biomol. Chem. 2005, 3, 719; e) B. List, J.-W. Yang, Science 2006, 313, 1584; f) B. List, Chem. Commun. 2006, 819; g) M. J. Gaunt, C. C. C. Johansson, A. McNally, N. C. Vo, Drug Discovery Today 2007, 2, 8; h) P. I. Dalko, Enantioselective Organocatalysis, Wiley-VCH, Weinheim (Germany), 2007; i) Chem. Rev. 2007, 107, Issue 12, special issue on organocatalysis; j) A. Dondoni, A. Massi, Angew. Chem. 2008, 120, in press; Angew. Chem. Int. Ed. 2008, 47, in press.

[2] For recent reviews of $\alpha$-functionalisations using enamine activation see, for example: a) J. M. Betancort, C. F. Barbas III, Org. Lett. 2001, 3, 3737; b) M. Marigo, K. A. Jørgensen, Chem. Commun. 2006, 2001; c) G. Guillena, D. J. Ramón, Tetrahedron: Asymmetry 2006, 17, 1465; d) S. Bertelsen, M. Nielsen, K. A. Jørgensen, Angew. Chem. 2007, 119, 7500; Angew. Chem. Int. Ed. 2007, 46, 7356. For examples see: e) J. Alemán, S. Cabrera, E. Maerten, J. Overgaard, K. A. Jørgensen, Angew. Chem. 2007, 119, 5616; Angew. Chem. Int. Ed. 2007, 46, 5520; f) M. Tiecco, A. Carlone, S. Sternativo, F. Marini, G. Bartoli, P. Melchiorre, Angew. Chem. 2007, 119, 7006; Angew. Chem. Int. Ed. 2007, 46, 6882; g) C. Palomo, S. Vera, I. Velilla, A. Mielgo, E. Gómez-Bengoa, Angew. Chem. 2007, 119, 8200; Angew. Chem. Int. Ed. 2007, 46, 8054

[3] For recent reviews on conjugated additions using iminium-ion activation see, for example: a) S. B. Tsogoeva, Eur. J. Org. Chem. 2007, 1701; b) D. Almasi, D. A. Alonso, C. Najera, Tetrahedron: Asymmetry 2007, 18, 299; c) J. L. Vicario, D. Badía, L. Carrillo, Synthesis 2007, 2065. For examples see e.g.: d) K. A. Ahrendt, C. J. Borths, D. W. C. MacMillan, J. Am. Chem. Soc. 2000, 122, 4243; e) M. Marigo, J. Fránzen, T. B. Poulsen, W. Zhuang, K. A. Jørgensen, J. Am. Chem. Soc. 2005, 127, 4790; f) S. Brandau, A. Landa, J. Franzén, M. Marigo, K. A. Jørgensen, Angew. Chem. 2006, 118, 4411; Angew. Chem. Int. Ed. 2006, 45, 4305; g) H. Gotoh, R. Masui, H. Ogino, M. Shoji, Y. Hayashi, Angew. Chem. 2006, 118, 7007; Angew. Chem. Int. Ed. 2006, 45, 6853; h) S. Mayer, B. List, Angew. Chem. 2006, 118, 4299; Angew. Chem. Int. Ed. 2006, 45, 4193; i) W. Wang,
H. Li, J. Wang, L. Zu, J. Am. Chem. Soc. 2006; 128, 10354; j) S. Brandau, E. Maerten, K. A. Jørgensen, J. Am. Chem. Soc. 2006, 128 , 14986; k) Y. K. Chen, M. Yoshida, D. W. C. MacMillan, J. Am. Chem. Soc. 2006, 128, 9328; 1) I. Ibrahem, R. Rios, J. Vesely, G. Zhao, A. Córdova, Chem. Commun. 2007, 849; m) J. Vesely, I. Ibrahem, G. Zhao, R. Rios, A. Córdova, Angew. Chem. 2007, 119, 792; Angew. Chem. Int. Ed. 2007, 46, 778; n) S. Bertelsen, P. Dinér, R. L. Johansen, K. A. Jørgensen, J. Am. Chem. Soc. 2007, 129, 1536; o) P. Dinér, M. Nielsen, M. Marigo, K. A. Jørgensen, Angew. Chem. 2007, 119, 2029; Angew. Chem. Int. Ed. 2007, 46, 1983; p) A. Carlone, G. Bartoli, M. Bosco, L. Sambri, P. Melchiorre, Angew. Chem. 2007, 119, 4588; Angew. Chem. Int. Ed. 2007, 46, 4504; q) I. Ibrahem, R. Rios, J. Vesely, P. Hammar, L. Eriksson, F. Himo, A Cordova, Angew. Chem. 2007, 119, 4591; Angew. Chem. Int. Ed. 2007, 46 4507; r) E. Maerten, S. Cabrera, A. Kjærsgaard, K. A. Jørgensen, J. Org. Chem. 2007, 72, 8893; s) M. Rueping, E. Sugiono, E. Merino, Angew. Chem. 2008, 120, 3089; Angew. Chem. Int. Ed. 2008, 47, 3046.

[4] a) S. Bertelsen, M. Marigo, S. Brandes, P. Dinér, K. A. Jørgensen, $J$. Am. Chem. Soc. 2006, 128, 12973; b) B. Hong, M. Wu, H. Tseng, J. Liao, Org. Lett. 2006, 8, 2217; c) B. J. Bench, C. Liu, C. R. Evett, C. M. H. Watanabe, J. Org. Chem. 2006, 71, 9458; d) B.-C. Hong, M.-F. Wu, H.-C. Tseng, G.-F. Huang, C.-F. Su, J.-H. Liao, J. Org. Chem. 2007, 72, 8459; e) R. M. de Figueiredo, R. Fröhlich, M. Christmann, Angew. Chem. 2008, 120, 1472; Angew. Chem. Int. Ed. 2008, 47, 1450 .

[5] For examples see: a) M. P. Sibi, M. Hasegawa, J Am. Chem. Soc. 2007, 129, 4124; b) H. Kim, D. W. C. MacMillan, J. Am. Chem. Soc. 2008, 130, 398 and references therein.

[6] For nomenclature regarding multicomponent reactions, see: a) C. J. Chapman, C. G. Frost, Synthesis 2007, 1 and references herein. For recent reviews on multicomponent reactions see for example: b) D. Tejedor, D. Gonzalez-Cruz, A. Santos-Expositto, J. J. Marrero-Tellado, P. de Armas, F. Garcia-Tellado, Chem. Eur. J. 2005, 11, 3502; c) D. J. Ramón, M. Yus, Angew. Chem. 2005, 117, 1628; Angew. Chem. 2005, 44, 1602; d) F. Liéby-Muller, C. Simon, T. Constantieux, J. Rodriguez, QSAR Comb. Sci. 2006, 25, 432; e) H. Guo, J. Ma, Angew. Chem. 2006, 118, 362; Angew. Chem. Int. Ed. 2006, 45, 354; f) D. Enders, C. Grondal, M. R. M. Hüttl, Angew. Chem. 2007, 119, 1590; Angew. Chem. Int. Ed. 2007, 46, 1570; g) G. Guillena, D. J. Ramón, M. Yus, Tetrahedron: Asymmetry 2007, 18, 693. For examples of one-pot multicomponent reactions involving conjugated addition see: h) T. Bui, C. F. Barbas, III, Tetrahedron Lett. 2000, 41, 6951; i) T. Itoh, M. Yokoya, K. Miyauchi, K. Nagata, A. Ohsawa, Org. Lett. 2003, 5, 4301; j) N. Halland, P. S. Aburel, K. A. Jørgensen, Angew. Chem. 2004, 116, 1292; Angew. Chem. Int. Ed. 2004, 43, 1272 ; k) Y. Yamamoto, N. Momiyama, H. Yamamoto, J. Am. Chem. Soc. 2004, 126, 5962; 1) J. W. Yang, M. T. Hechavarria Fonseca, B. List, J. Am. Chem. Soc. 2005, 127, 15036; m) Y. Huang, A. Walji, C. H. Larsen, D. W. C. MacMillan, J. Am. Chem. Soc. 2005, 127, 15051; n) M. Marigo, T. Schulte, J. Franzén, K. A. Jørgensen, J. Am. Chem. Soc. 2005, 127, 15710; o) M. Rueping, A. P. Antonchick, T. Theissmann, Angew. Chem. 2006, 118, 3765; Angew. Chem. Int. Ed. 2006, 45, 3683; p) M. Marigo, S. Bertelsen, A. Landa, K. A. Jørgensen, J. Am. Chem. Soc. 2006, 128, 5475; q) S. Brandau, E. Maerten, K. A. Jørgensen, J. Am. Chem. Soc. 2006, 128, 14986; r) A. Carlone, M. Marigo, C. North, A. Landa. K. A. Jørgensen, Chem. Commun. 2006, 4928; s) D. Enders, M. R. M. Hüttl, J. Runsink, G. Raabe, B. Wendt, Angew. Chem. 2007, 119, 471; Angew. Chem. Int. Ed. 2007, 46,$467 ;$ t) H. Sundén, I. Ibrahem, G.-L. Zhao, L. Eriksson, A. Córdova, Chem. Eur. J. 2007, 13, 574; u) A. Carlone, S. Cabrera, M. Marigo, K. A. Jørgensen, Angew. Chem. 2007, 119, 1119; Angew. Chem. Int. Ed. 2007, 46, 1101; v) H. Li, L. Zu, H. Xie, J. Wang, W. Jiang, W. Wang, Org. Lett. 2007, 9, 1833; w) J. Zhou, B. List, J. Am. Chem. Soc. 2007, 129, 7498; x) D. Enders, A. A. Narine, T. R. Benninghaus, G. Raabe, Synlett 2007, 1667; y) Y. Hayashi, T. Okano, S. Aratake, D. Hazelard, Angew. Chem. 2007, 119, 5010; Angew. Chem. Int. Ed. 2007, 46, 4922; z) H. Xie, L. Zu, H. Li, J. Wang, W. Wang, J. Am. Chem. Soc. 2007, 129, 10886. aa) P. T. Franke, R. L. 
Johansen, S. Bertelsen, K. A. Jørgensen, Chem. Asian J. 2008, 3, 216.

[7] a) A. Rahman, A. Nasreen, F. Akhtar, M. S. Shekhani, J. Clardy, M. Parvez, M. I. Choudhary, J. Nat. Prod. 1997, 60, 472; b) M. A. Brimble, H. Prabaharan, Tetrahedron 1998, 54, 2113; c) J. C. Conway, P. Quayle, A. C. Regan, C. J. Urch, Tetrahedron 2005, 61, 11910; d) R. H. Liu, W. D Zhang, Z. B. Gu, C. Zhang, J. Su, X. K. Xu, Nat. Prod. Res. 2006, 20, 866; e) E. L. Larghi, T. S. Kaufman, Synthesis 2006, 187; f) Y. Tang, J. Oppenheimer, Z. Song, L. You, X. Zhang, R. P. Hsung, Tetrahedron 2006, 62, 10785; g) M. Shoji, Y. Hayashi, Eur. J. Org. Chem. 2007, 3783; h) E. D. Goddard-Boger, E. L. Ghisalberti, R. V. Stick, Eur. J. Org. Chem. 2007, 3925; i) J. C. R. Brioche, K. M. Goodenough, D. J. Whatrup, J. P. A. Harrity, J. Org. Chem. 2008, 73, 1946; j) S. Kumar, W. P. Malachowski, J. B. DuHadaway, J. M. LaLonde, P. J. Carroll, D. Jaller, R. Metz, G. C. Prendergast, A. J. Muller, J. Med. Chem. 2008, 51, 1706; k) N. H. Yoo, D. S. Jang, J. L. Yoo, Y. M. Lee, Y. S. Kim, J.-H. Cho, J. S. Kim, J. Nat. Prod. 2008, 71, 713 .

[8] a) W. S. Emerson, G. H. Birum, R. I. Longley, J. Am. Chem. Soc. 1953, 75, 1312; b) B. B. Snider, Tetrahedron Lett. 1980, 21, 1133; c) M. Maier, R. R. Schmidt, Liebigs Ann. Chem. 1985, 2261; d) Y. Chapleur, M.-N. Euvrard, J. Chem. Soc. Chem. Commun. 1987, 884; e) R. A. John, V. Schmid, H. Wyler, Helv. Chim. Acta 1987, 70, 600; f) W. H. Bunnelle, L. A. Meyer, J. Org. Chem. 1988, 53, 4038; g) L. F. Tietze, H. Meier, H. Nutt, Chem. Ber. 1989, 122, 643; h) H.
Al-Badri, N. Collignon, J. Maddaluno, S. Masson, Chem. Commun. 2000, 1191; i) A. Palasz, K. Jelska, M. Ozog, P. Serda, Monatsh Chem. 2007, 138, 481.

[9] Applications as catalysts: a) M. Marigo, T. C. Wabnitz, D. Fielenbach, K. A. Jørgensen, Angew. Chem. 2005, 117, 804; Angew. Chem. Int. Ed. 2005, 44, 794. See also: b) M. Marigo, D. Fielenbach, A. Braunton, A. Kjærsgaard, K. A. Jørgensen, Angew. Chem. 2005, 117, 3769; Angew. Chem. Int. Ed. 2005, 44, 3703; c) Y. Hayashi, H. Gotoh, T. Hayashi, M. Shoji, Angew. Chem. 2005, 117, 4284; Angew. Chem. Int. Ed. 2005, 44, 4212; d) J. Franzén, M. Marigo, D. Fielenbach, T. C. Wabnitz, A. Kjærsgaard, K. A. Jørgensen, J. Am. Chem. Soc. 2005, 127, 18296; e) C. Palomo, A. Mielgo, Angew. Chem. 2006, 118, 8042; Angew. Chem. Int. Ed. 2006, 45, 7876.

[10] Examples of similar results: a) E. Reyes, H. Jiang, A. Milelli, P. Elsner, R. G. Hazell, K. A. Jørgensen, Angew. Chem. 2007, 119, 9362; Angew. Chem. Int. Ed. 2007, 46, 9202; b) C. Palomo, A. Landa, A. Mielgo, M. Oiarbide, A. Puente, S. Vera, Angew. Chem. 2007, 119, 8737; Angew. Chem. Int. Ed. 2007, 46, 8583.

[11] CCDC-687038 (3e) contain the supplementary crystallographic data for this paper. These data can be obtained free of charge from The Cambridge Crystallographic Data Centre via www.ccdc.cam.ac.uk/ data_request/cif
Received: May 5, 2008 Published online: June 5, 2008 